University of Nebraska - Lincoln

DigitalCommons@University of Nebraska - Lincoln

4-16-2021

\title{
Late-seeded cover crops in a semiarid environment: overyielding, dominance and subsequent crop yield
}

\author{
John R. Hendrickson \\ Northern Great Plains Research Laboratory \\ Mark A. Liebig \\ Northern Great Plains Research Laboratory \\ David W. Archer \\ Northern Great Plains Research Laboratory \\ Marty Schmer \\ USDA, marty.schmer@ars.usda.gov \\ Kristine A. Nichols \\ Northern Great Plains Research Laboratory
}

See next page for additional authors

Follow this and additional works at: https://digitalcommons.unl.edu/usdaarsfacpub

Part of the Agriculture Commons

Hendrickson, John R.; Liebig, Mark A.; Archer, David W.; Schmer, Marty; Nichols, Kristine A.; and Tanaka, Donald L., "Late-seeded cover crops in a semiarid environment: overyielding, dominance and subsequent crop yield" (2021). Publications from USDA-ARS / UNL Faculty. 2522.

https://digitalcommons.unl.edu/usdaarsfacpub/2522

This Article is brought to you for free and open access by the U.S. Department of Agriculture: Agricultural Research Service, Lincoln, Nebraska at DigitalCommons@University of Nebraska - Lincoln. It has been accepted for inclusion in Publications from USDA-ARS / UNL Faculty by an authorized administrator of DigitalCommons@University of Nebraska - Lincoln. 


\section{Authors}

John R. Hendrickson, Mark A. Liebig, David W. Archer, Marty Schmer, Kristine A. Nichols, and Donald L. Tanaka 
Renewable Agriculture and

Food Systems

\section{cambridge.org/raf}

\section{Research Paper}

Cite this article: Hendrickson JR, Liebig MA, Archer DW, Schmer MR, Nichols KA, Tanaka DL (2021). Late-seeded cover crops in a semiarid environment: overyielding, dominance and subsequent crop yield. Renewable Agriculture and Food Systems 36, 587-598. https://doi.org/ $10.1017 / \mathrm{S} 174217052100020 \mathrm{X}$

Received: 7 December 2020

Revised: 22 March 2021

Accepted: 16 April 2021

First published online: 20 May 2021

\section{Key words:}

Cool-season cover crops; diversity indices; growing degree days (GDD); semi-arid cropping systems; warm-season cover crops

Author for correspondence:

John R. Hendrickson,

E-mail: john.hendrickson@ars.usda.gov

\section{Late-seeded cover crops in a semiarid environment: overyielding, dominance and subsequent crop yield}

\author{
John R. Hendrickson ${ }^{1}$ (D), Mark A. Liebig ${ }^{1}$ (D), David W. Archer ${ }^{1}$ (D), \\ Marty R. Schmer ${ }^{1,2}$ (D) Kristine A. Nichols ${ }^{1,3}$ and Donald L. Tanaka ${ }^{1}$
}

${ }^{1}$ Northern Great Plains Research Laboratory, USDA-ARS Box 459, Mandan, ND 58554, USA; ${ }^{2}$ Agroecosystem Management Research Unit, 137 Keim Hall, Univ. Nebr., Lincoln, NE 68583, USA and ${ }^{3}$ KRIS-Systems, 6625 E. 3rd Street, Scottsdale, AZ 85251, USA

\begin{abstract}
Interest in cover crops is increasing but information is limited on integrating them into crop rotations especially in the relatively short growing season on the northern Great Plains. A 3-yr research project, initiated in 2009 near Mandan, North Dakota, USA, evaluated (1) what impact cover crops may have on subsequent cash crops yields and (2) whether cover crop mixtures are more productive and provide additional benefits compared to cover crop monocultures. The study evaluated 18 different cover crop monocultures and mixtures that were seeded in August following dry pea (Pisum sativum L.). The following year, spring wheat (Triticum aestivum L.), corn (Zea mays L.), soybean (Glycine max L.) and field pea were seeded into the different cover crop treatments and a non-treated control. A lack of timely precipitation in 2009 resulted in a low cover crop yield of $17 \mathrm{~g} \mathrm{~m}^{2}$ compared to 100 and $77 \mathrm{~g} \mathrm{~m}^{2}$ in 2008 and 2010, respectively. Subsequent cash crop yield was not affected by late-seeded cover crops. Cool-season cover crop monocultures were more productive than warm-season monocultures and some mixtures in 2008 and 2010. Relative yield total did not differ from one in any cover crop mixture suggesting that overyielding did not occur. Species selection rather than species diversity was the most important contributor to cover crop yield. Cover crops can be grown following short-season cash crops in the northern Great Plains, but precipitation timing and species selection are critical.
\end{abstract}

\section{Introduction}

Integrating cover crops is one approach to sustainably intensifying cropping systems. Cover crops can provide the benefits of adopting cover crops and add production costs to agronomic systems (Snapp et al., 2005). Benefits include ecosystem services such as, promoting cash crop productivity, enhancing overall soil fertility (Blanco-Canqui et al., 2012), soil and water conservation, nutrient scavenging, cycling and management, enhancing pest management strategies and providing livestock feed (Delgado et al., 2007). Costs can include increased production costs, planting delays (Snapp et al., 2005) and the potential to reduce subsequent cash crop yield due to soil moisture depletion (Nielsen et al., 2015). In Illinois, seeding a cereal rye (Secale cereal L.) and daikon radish (Raphanus sativus L.) cover crop mixture at $84 \mathrm{~kg} \mathrm{ha}^{-1}$ seeding rate, cost between $\$ 116-117 \mathrm{ha}^{-1}$ to establish (Roth et al., 2018). If full season cover crops are used, the opportunity cost of lost cash crop income for the year needs to be considered (Snapp et al., 2005) in addition to the production costs of the cover crops.

Seeding cover crops following cash crops in the same growing season may reduce lost opportunity costs associated with cover crop production, especially if there are benefits to the subsequent crop. In the northern Great Plains, a short growing season, limited soil moisture (Farahani et al., 1998) and variable climate can restrict crop production. Producers in the region have adopted no-till planting (Hansen et al., 2012), which increases available soil moisture and resulted in producers looking to increase crop diversity (Aguilar et al., 2015). The desire to enhance crop diversity increased interest in using including short season pulse crops such as dry pea (Pisum sativum L.) in the rotation. Because of this interest, dry pea harvested acreage in North Dakota increased from 38,850 hectares in 1998 to 161,874 hectares in 2010 (NASS, 2020). The early harvest of dry pea provides opportunities for seeding a lateseason cover crop in the same growing season. Liebig et al. (2015) reported on an established study in Mandan, North Dakota that evaluated the impact of late-seeded cover crop monocultures and mixtures on nitrogen conservation, soil water and near-surface soil properties.

Improvement in cash crop yields was one of the top three benefits that non-users of cover crops would look for in cover crops (SARE and CTIC, 2015). However, while producers have reported increases in corn, wheat and soybean yields following cover crops (CTIC, 2017), 
research findings have been much less definitive. An review by Blanco-Canqui et al. (2015) indicated cover crops can increase, decrease or have no effect on crop yield while a meta-analysis of 65 studies conducted between 1965 and 2015 indicated that winter cover crops had no impact on corn yield (Marcillo and Miguez, 2017). Still, there have been reports of increased corn yield in Michigan when it was grown with a red clover cover crop compared to no cover crops (Mutch and Martin, 1998) and in California, dryland wheat yields did not differ between fertilized plots that were fallowed and unfertilized plots that were fallowed but had cover crop biomass added (McGuire et al., 1998). The impact of cover crop mixture $v s$ monocultures on crop yield is also unclear. For example, a New Hampshire study demonstrated no differences in oat yields that followed cover crop mixtures or monocultures (Smith et al., 2014). Interestingly, in eastern Colorado and western Nebraska water use was the same for cover crop mixtures and cover crop monocultures (Nielsen et al., 2015).

The impact of diversity in cover crops has received less emphasis (Wortman et al., 2012a) than it has in perennial crops (Tilman et al., 2001). Using multi-species cover crop mixtures and diverse crop rotations may allow producers to capture the benefits of cover crops without sacrificing yield (Hunter et al., 2019). An evaluation of mixtures $v s$ monocultures in multiple sites in southeastern Nebraska, found increased productivity with mixtures (Florence et al., 2019). The authors believed the mixtures were more productive because average productivity for the monocultures was decreased by poor performers. Species composition may also impact productivity. Murrell et al. (2017) found that grasses overperformed and brassicas underperformed in mixtures compared to monocultures. Although, mixtures may not be more productive, increasing diversity in row-crop systems can improve ecosystem functioning and enhance corn yield (Smith et al., 2008).

The controversy about the positive effect of species diversity on productivity may exist because mechanisms responsible for providing the productivity increase are unidentified (Cardinale et al., 2012). One of the common measurements of the positive effect of diversity is overyielding (Bonin and Tracy, 2012), the process where a species yields more in a mixture than in a monoculture. This has reported in cover crop mixtures in both Nebraska (Wortman et al., 2012b) and New Hampshire (Smith et al., 2014). Overyielding is generally considered to be either transgressive (the mixture produces more than the most productive monoculture) or non-transgressive (the species in the mixture produce more than expected by the monoculture yields but do not out-yield the most productive species).

Although these two measures can help detect overyielding, they do not provide insights into how overyielding occurs (Hector, 2006; Bonin and Tracy, 2012). Overyielding can occur because of niche differentiation or facilitation [complementary effects (CEs)], or because of a selection process that favors species with certain traits [selection effects (SEs)] (Loreau and Hector, 2001). If overyielding occurs in cover crop mixtures, understanding why it occurs can help in developing cover crop mixtures.

This paper reports on two additional hypotheses developed for the same study. We hypothesized that (1) the inclusion of cover crops would positively benefit subsequent crop yields and (2) cover crop mixtures would be more productive and provide greater subsequent cash crop yield benefits than would cover crop monocultures. We also evaluated if overyielding occurred in late-seeded cover crop mixtures and if so, what mechanisms led to this overyielding.

\section{Materials and methods}

\section{Site description}

Three research sites, located on the Area IV Soil Conservation Districts (SCD) Research Farm $\sim 6 \mathrm{~km}$ south of Mandan, ND $\left(46^{\circ}\right.$ $\left.46^{\prime} 12^{\prime \prime} \mathrm{N}, 100^{\circ} 54^{\prime} 57^{\prime \prime} \mathrm{W}\right)$, were used for each study year (20082010). The sites were $\sim 2 \mathrm{~km}$ apart and had the same management history, topography and soil type. Soils were dominated by a mix of Temvik and Wilton silt loams (USDA: fine-silty superactive, frigid Typic and Pachic Haplustolls; FAO: Calcic Siltic Chernozems). Long-term (98 yr) mean annual precipitation is $412 \mathrm{~mm}$, with $79 \%$ of the total received during the growing season (AprilSeptember) and long-term mean annual temperature averages $4^{\circ} \mathrm{C}$.

\section{Weather data}

Weather data were collected from a North Dakota Agricultural Weather Network (NDAWN) station located within $3 \mathrm{~km}$ of the research sites (NDAW-North Dakota Agricultural Weather Network, 2016). Weather data collection was initiated with cover crop planting. Cool-season growing degree days (GDD) were based on the canola GDD, which was calculated without a maximum temperature and with a $5^{\circ} \mathrm{C}$ base temperature. The warmseason GDD were based on the corn GDD, which was calculated using a maximum of $30^{\circ} \mathrm{C}$ and a minimum of $10^{\circ} \mathrm{C}$. The formulas for both GDD calculations can be found at the NDAWN web site (NDAWN, 2016). Precipitation was recorded for the study period at the same location, again initiating at the same time as cover crops were seeded. Precipitation for the cash crops was recorded from April through October at the same location.

Precipitation during the cover crop growing season was 50 and $75 \%$ greater in 2009 and 2010 than in 2008 (Fig. 1). The longest lapse between cover crop seeding and the initial precipitation event $>1 \mathrm{~mm}$ was 16 days in 2009. 2010 had the longest growing season for cover crops (Fig. 1). Both warm- and cool-season GDD were consistent between years. Warm-season GDD only varied by 5 GDD between years while cool-season GDD varied by 17 GDD. April through October precipitation for the cash crops was 484, 481 and $508 \mathrm{~mm}$ for 2009, 2010 and 2011, respectively.

\section{Field activities}

In April 2008, an 8 ha field was seeded to dry pea (Pisum sativum L.) at a seeding rate of 141,700 viable seeds $\mathrm{ha}^{-1}$ using a John Deere 750 (Deere \& Company, Moline, IL) no-till drill with a $19 \mathrm{~cm}$ row spacing. The dry peas were inoculated prior to seeding with Rhizobium leguminosarium. Dry pea was harvested in early August using a John Deere 4420 combine and the residue evenly spread over the soil surface. In 2009 and 2010, nearby sites ( $2 \mathrm{~km}$ apart) with the same management history, topography and soil type were seeded to dry pea prior to the initiation of cover crop treatments.

Cover crops were seeded into the dry pea stubble in each year. Individual cover crop plots were $9.1 \times 36.6 \mathrm{~m}$. Planting dates for the cover crops were August 21-22 in 2008 and August 25-26 in 2009 and 2010. None of the cover crop treatments were fertilized or inoculated. Treatments consisted of seven different cover crop monocultures; each in a different functional group and a series of cover crop mixtures, which included the same seven cover crops but had selected functional groups removed from the mixture. Cover crops used in the study included (1) winter canola (WC) (Brassica napus L.); (2) vine pea (VP) (Pisum sativum L.); (3) spring triticale (ST) (Triticosecale Wittmarck); 


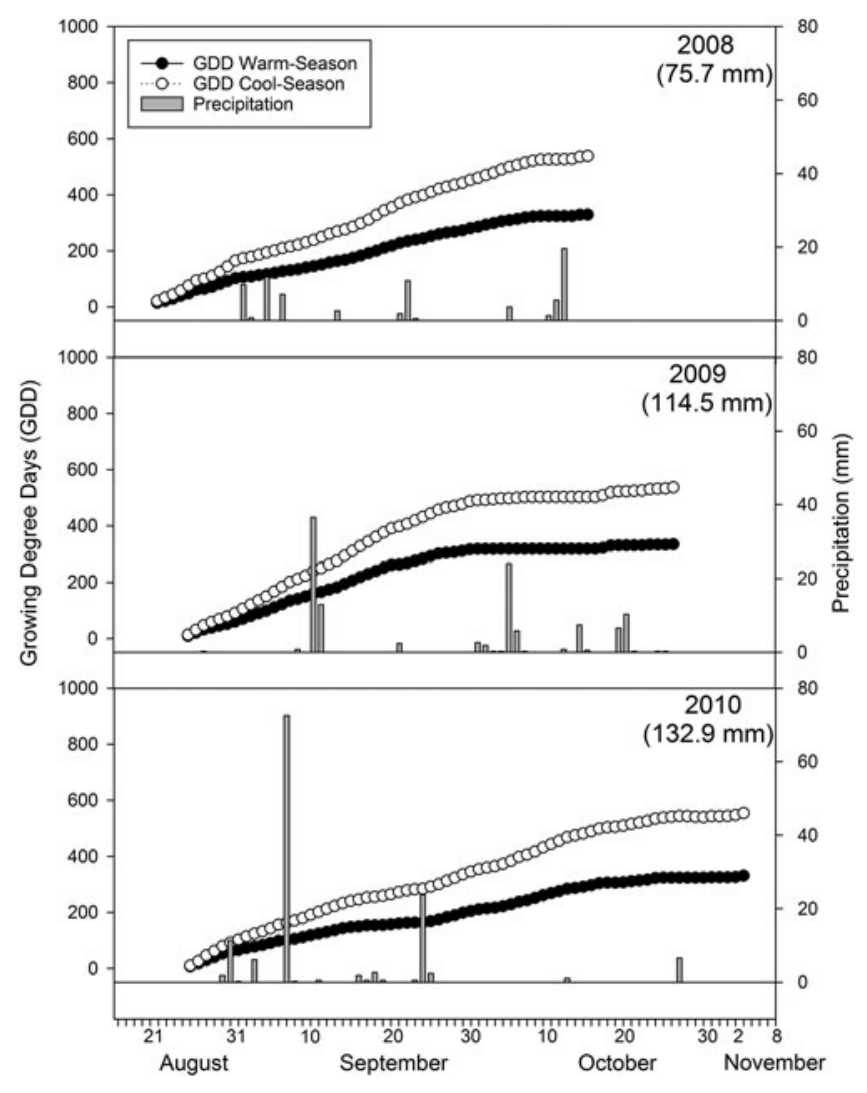

Fig. 1. Warm-season and cool-season growing degree day (GDD) accumulation and precipitation events recorded after the seeding of the cover crops for 2008, 2009 and 2010. The numbers in parentheses below the year indicate the amount of precipitation between cover crop seeding and harvest.

(4) sunflower (SF) (Helianthus annuus L.); (5) soybean (S) (Glycine max L); (6) purple top turnip (PTT) (Brassica rapa var rapa); and (7) proso millet (PM) (Panicum miliaceum L). Functional groups in this study included warm-season crops (SF, S, PM); cool-season crops (WC, VP, ST); grasses (ST, PM); legumes (S, VP); forbs (WC, SF) and a root crop (PTT). On certain treatments, an entire functional group was removed. For example, in the DPMST treatment, grasses were removed (Table 1). Other functional groups that were excluded include legumes (DSVP), forbs (DWCSF) and root crops (DPTT). All treatments, the acronyms and functional groups or cover crop mixture composition are listed in Table 1.

Besides the cover crop treatments, a non-seeded control (CON) was included in all years (2008, 2009 and 2010). In 2009 and 2010, an additional non-seeded plot was mechanically disturbed using the no-till drill (COND) (Table 1). This plot was included to isolate the impact of cover crops from any planting operation effect.

Seeding rates for the cover crops are included in the Supplementary material. Cover crops were seeded with a John Deere 750 No-Till drill on $19 \mathrm{~cm}$ row spacing. Selection of the cover crop treatments and the seeding rates were determined in consultation with area farmers and SCD personnel (Liebig et al., 2015). In seeding, rates were substitutive rather than additive and the seeding rate of an individual species decreased as the number of species in the mixture increased. In the case of the mixture of all the cover crops (ALL), the seeding rate was $1,124,446$ viable seeds $\mathrm{ha}^{-1}$. While a different site was used for
Table 1. Listing of the cover crop treatments, the acronyms used and the functional group of the monoculture or the composition of species mixtures

\begin{tabular}{|c|c|}
\hline Acronym & Monoculture functional group/mixture composition \\
\hline \multicolumn{2}{|c|}{ Monocultures } \\
\hline WC & Cool-season forb \\
\hline VP & Cool-season legume \\
\hline ST & Cool-season grass \\
\hline SF & Warm-season forb \\
\hline $\mathrm{S}$ & Warm-season legume \\
\hline PTT & Root-crop \\
\hline PM & Warm-season grass \\
\hline \multicolumn{2}{|l|}{ Mixtures } \\
\hline ALL & Mixture of all monocultures \\
\hline DWC & Removal of cool-season forb from mixture \\
\hline DSF & Removal of warm-season forb from mixture \\
\hline DWCSF & Removal of forbs from mixture \\
\hline DVP & Removal of cool-season legume from mixture \\
\hline DS & Removal of warm-season legume from mixture \\
\hline DSVP & Removal of legumes from mixture \\
\hline DST & Removal of cool-season grass from mixture \\
\hline DPM & Removal of warm-season grass from mixture \\
\hline DPMST & Removal of grasses from mixture \\
\hline DPTT & Removal of root-crop from mixture \\
\hline \multicolumn{2}{|c|}{ Non-seeded controls } \\
\hline CON & All years \\
\hline COND & In 2009 and 2010 only \\
\hline
\end{tabular}

Only the cover crops removed from the mixture are listed. All other cover crops remained in the mixture.

the cover crop seeding each year, the soil and initial field preparation were similar between years.

Beginning in 2009 and continuing in 2010 and 2011, four cash crops, spring wheat (Triticum aestivum L.), corn (Zea mays L.), soybean (Glycine max L.) and dry pea were seeded in strips $(9.1 \times 180$ $\mathrm{m})$ perpendicular to the cover crop treatments each year. Therefore, plot size for determining impact of a cover crop treatment on response crop yield was $9.1 \times 9.1 \mathrm{~m}$. Timing of field operations and the amounts of inputs for the cash crops are listed in Table 2. Yield data from the four cash crops were collected using a Hege 140 (Hege Equipment; Colwich, KS) small plot combine that harvested a $1.5 \mathrm{~m}$ central strip from each plot. More details on field experiments and soil properties are reported in Liebig et al. (2015).

\section{Cover crop biomass estimations}

Cover crop yield was estimated by clipping two $1 / 4 \mathrm{~m}^{2}$ quadrats per plot in the wheat response strip (see below) following one or more killing frosts in the fall. Because some species in the cover crop mixtures continued to grow after light frosts, delaying clipping was necessary to reach maximum yield. Harvest dates were October 15, 2008; October 26, 2009 and November 2, 2010. All cover crops and any weeds and/or non-target plant species were clipped to ground level and separated by species within each 
Table 2. Management practices for response crops following cover crop treatments near Mandan, ND

\begin{tabular}{|c|c|c|c|}
\hline \multicolumn{4}{|l|}{2009} \\
\hline Response crop & Date & Activity & Data \\
\hline Dry pea & 05/14/2009 & Planting & cv: DS Admiral \\
\hline Spring wheat & 05/20/2009 & Planting & cv: Howard \\
\hline Spring wheat & 05/20/2009 & Fertilizing & $67 \mathrm{~N} \mathrm{~kg} \mathrm{ha}^{-1}$ \\
\hline Corn & 05/22/2009 & Planting & cV: Legend 9780RB \\
\hline Spring wheat & 06/20/2009 & Spraying & Fenoxaprop $\left(0.6 \mathrm{~L} \mathrm{ha}^{-1}\right)$, bromoxynil $\left(1.1 \mathrm{Lha}^{-1}\right)$ \\
\hline Dry pea & 06/22/2009 & Spraying & Sethoxydim $\left(3.8 \mathrm{~L} \mathrm{ha}^{-1}\right)$ plus adjuvants (ammonium sulfate, methylated seed oil), indobutryic acid $\left(0.15 \mathrm{~L} \mathrm{ha}^{-1}\right)$ \\
\hline Dry pea & 09/02/2009 & Harvest & \\
\hline Spring wheat & 09/04/2009 & Harvest & \\
\hline Corn & $11 / 20 / 2009$ & Harvest & \\
\hline Soybean & 06/03/10 & Planting & cV: Legend 0439RR \\
\hline Corn & $06 / 01 / 10$ & Planting & cV: Legend 9780RB \\
\hline Corn and soybean & 06/02/10 & Spraying & Glyphosate $\left(1.1 \mathrm{~L} \mathrm{ha}^{-1}\right)$, carfentrazone $\left(0.04 \mathrm{~L} \mathrm{ha}^{-1}\right)$ and adjuvant (ammonium sulfate) \\
\hline Dry pea & $06 / 15 / 10$ & Spraying & Sethoxydim $\left(3.8 \mathrm{~L} \mathrm{ha}^{-1}\right)$ and adjuvant (methylated seed oil $1.5 \mathrm{~L} \mathrm{ha}^{-1}$ ) \\
\hline Spring wheat & $06 / 23 / 10$ & Spraying & Fenoxaprop $\left(0.6 \mathrm{~L} \mathrm{ha}^{-1}\right)$, bromoxynil $\left(1.1 \mathrm{Lha}^{-1}\right)$, pyraclostrobin $\left(0.2 \mathrm{~L} \mathrm{ha}^{-1}\right)$. \\
\hline Soybean & $07 / 08 / 10$ & Spraying & Glyphosate $\left(1.1 \mathrm{l} \mathrm{ha}^{-1}\right)$, diflufenzpoyr and dicamba $\left(0.18 \mathrm{~L} \mathrm{ha}^{-1}\right)$ \\
\hline Corn & 07/09/10 & Spraying & Glyphosate $\left(1.1 \mathrm{~L} \mathrm{ha}^{-1}\right)$, diflufenzpoyr and dicamba $\left(0.18 \mathrm{~L} \mathrm{ha}^{-1}\right)$ \\
\hline Dry pea & $08 / 09 / 10$ & Harvest & \\
\hline Spring wheat & $09 / 14 / 10$ & Harvest & \\
\hline Soybean & $11 / 08 / 10$ & Harvest & \\
\hline Corn & $11 / 05 / 10$ & Harvest & \\
\hline
\end{tabular}




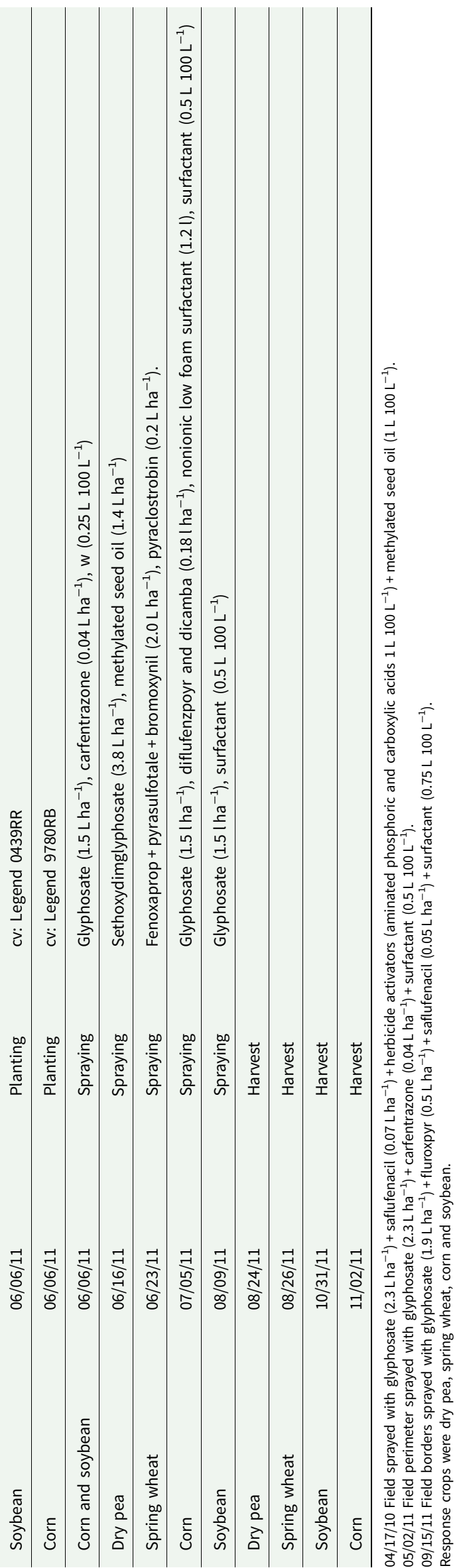

quadrat. One quadrat was placed toward the outside of each plot while the other was placed near the center of the plot. Following collection, yield samples were dried for 2 days at $60^{\circ} \mathrm{C}$. Yield from both quadrats was composited in the field for $1 / 2 \mathrm{~m}^{2}$ quadrats for yield estimation. Weed yield was different between years $(P=$ $0.0063)$ but not treatments $(P=0.5164)$ so weeds were not included in the total yield estimations.

\section{Overyielding calculations}

The cover crop mixtures were evaluated for overyielding using relative yield total (RYT). RYT evaluates whether the expected yield of species in a mixture is greater than the expected yield of the same species in a series of monocultures (Hector, 2006). The formula and interpretation for RYT is given in Table 3. Transgressive overyielding which indicates whether mixtures produce more than the best-performing monocultures was measured using $D_{\max }$ (Bonin and Tracy, 2012). The formula and interpretation for $D_{\max }$ is given in Table 3 .

CEs indicate if overyielding is due to ecological effects such as facilitation or niche partitioning (Bonin and Tracy, 2012). Measuring CE is determined by multiplying the number of species in the mixture by average deviation in relative yield $(\Delta R Y)$ and by the average monoculture yield (mean $M$ ) (Loreau and Hector, 2001). The formula and interpretation for $C E, \Delta R Y$ and mean $M$ are given in Table 3. SE which measures if overyielding is due to the presence of a specific species in the mixture (Bonin and Tracy, 2012) and is the species number multiplied by the covariance of deviation in relative yield and yield (Loreau and Hector, 2001). SE is positive and higher when the mixtures are dominated by the most productive monocultures. The formula for SE is in Table 3. Species dominance within a cover crop mixture was measured using the Berger-Parker dominance index $(d)$ (Berger and Parker, 1970). The proportion of the yield dominated by one species is determined by $d$. The formulas for the metrics and additional interpretation are in Table 3.

\section{Experimental design}

The experiment was set up as a randomized complete block with all treatments within each of the four blocks. Treatments were replicated four times within each year and the experiment was analyzed as a randomized complete block using PROC GLIMMIX (SAS 2012) with year and cover crop treatment as fixed effects and replicate nested within year as a random effect. Differences between treatment means were considered significant at $P \leq 0.10$ unless noted otherwise.

Overyielding indices were analyzed using PROC Univariate (SAS 2012) to determine if indices were significantly different from 1 , for RYT, or 0 for $D_{\max }$, CE and SE for each year and cover crop mixture. Since not all indices were normally distributed, normality was checked using the Anderson-Darling test (Anderson and Darling, 1952). If the index was normally distributed, Student's $t$-test was used to test for significance. The signed rank test was used for non-normally distributed indices.

\section{Results \\ Cover crop yields}

There were differences in cover crop yield between treatments and years. The maximum yield of the cover crops was only $17 \mathrm{~g} \mathrm{~m}^{2}$ in 
Table 3. Metrics for determining overyielding in the cover crop mixtures with the equations and interpretations

\begin{tabular}{|c|c|c|}
\hline Metric & Equation & Interpretation \\
\hline Relative yield total (RTY) & $\mathrm{RYT}=\sum R Y_{o i}$ & Overyielding occurs when RTY is greater than 1 . \\
\hline Complementary effects (CEs) & $\mathrm{CE}=S \times \operatorname{mean}\left(\Delta R Y_{i}\right) \times \operatorname{mean}\left(M_{i}\right)$ & $\begin{array}{l}\text { Positive CE indicates overyielding is due to processes such as facilitation or } \\
\text { niche differentiation. }\end{array}$ \\
\hline Berger-Parker dominance $(d)$ & $d=\frac{N_{\max }}{N}$ & Diversity decreases and dominance by one species increases as $d$ nears 1 . \\
\hline
\end{tabular}

Variables: $Y_{o}=$ observed total yield of a cover crop mixture; $S=$ number of species in the mixture; $M_{i}=$ average yield of species $i$ in monoculture; max $\left(M_{i}\right)=$ average monoculture yield of the best-performing species found in mixture; $O_{i}=$ observed yield of species $i$ in mixture; $E_{i}=M_{i} / S=$ expected yield of a species $i$ in mixture; $R Y_{o i}=O_{i} / M_{i}=$ observed relative yield of species $i$ in mixture; $R Y_{e i}=1 / S=$ expected relative yield of species $i$ in mixture; $\Delta R Y_{i}=R Y_{o i}-R Y_{e i} ; N_{\max }=$ biomass of the most productive cover crop; $N=$ total cover crop biomass for the plot. Equations and variables are adapted from Bonin and Tracy (2012).

2009 compared to 100 and $77 \mathrm{~g} \mathrm{~m}^{2}$ in 2008 and 2010, respectively. Cover crop yield was lower for all treatments in 2009 than in 2008 or 2010 (Fig. 2). Warm-season cover crops, such as SF, soybean and proso millet, did not produce large yields in any year $\left(0.07-12.9 \mathrm{~g} \mathrm{~m}^{2}\right)$. ST produced the greatest yield in 2009 and 2010 and the second greatest in 2008. There were no significant differences between the maximum monoculture yields and that of the high diversity mixture (ALL); the mixtures that dropped legumes (DSVP) and grasses (DPMST) or the mixture that dropped winter canola (DWC) in any year (Fig. 2). In general, yields of the cover crop mixtures were intermediate between spring triticale and the low producing warm-season cover crops.

\section{Response crop yields}

Year rather than cover crop treatment made the most impact on spring wheat, corn, soybean and dry pea grain yield. There were no differences in yields between any of the cover crop treatments for any of the cash crops within year (data not shown). However, there were differences in grain yields between years for all cash crops (Table 4).

\section{Overyielding effects}

Four different metrics were used to evaluate overyielding and its components (Table 3). Overyielding as measured by RYT was greater than 1 in 2010 and less than 1 in 2009 (Table 5). Of the 11 different cover crop mixtures DVP was less than 1 but all other mixtures were not different from 1. Overyielding as measured by $D_{\max }$ was significantly negative $(<0)$ for all years and cover crop mixtures except for DPMST (Table 5). The CE was negative in 2009 and positive in 2010 but did not differ from 0 for any of the cover crop mixtures (Table 5). The SE was positive for all three years and also for 9 of the 11 mixtures. The DSF did not differ from 0 while DST was negative $(\mathrm{SE}<0)($ Table 5$)$.

\section{Dominance measures}

The Berger-Parker dominance index $(d)$ had a year by treatment interaction. The $d$ index had significant differences in 2009 but

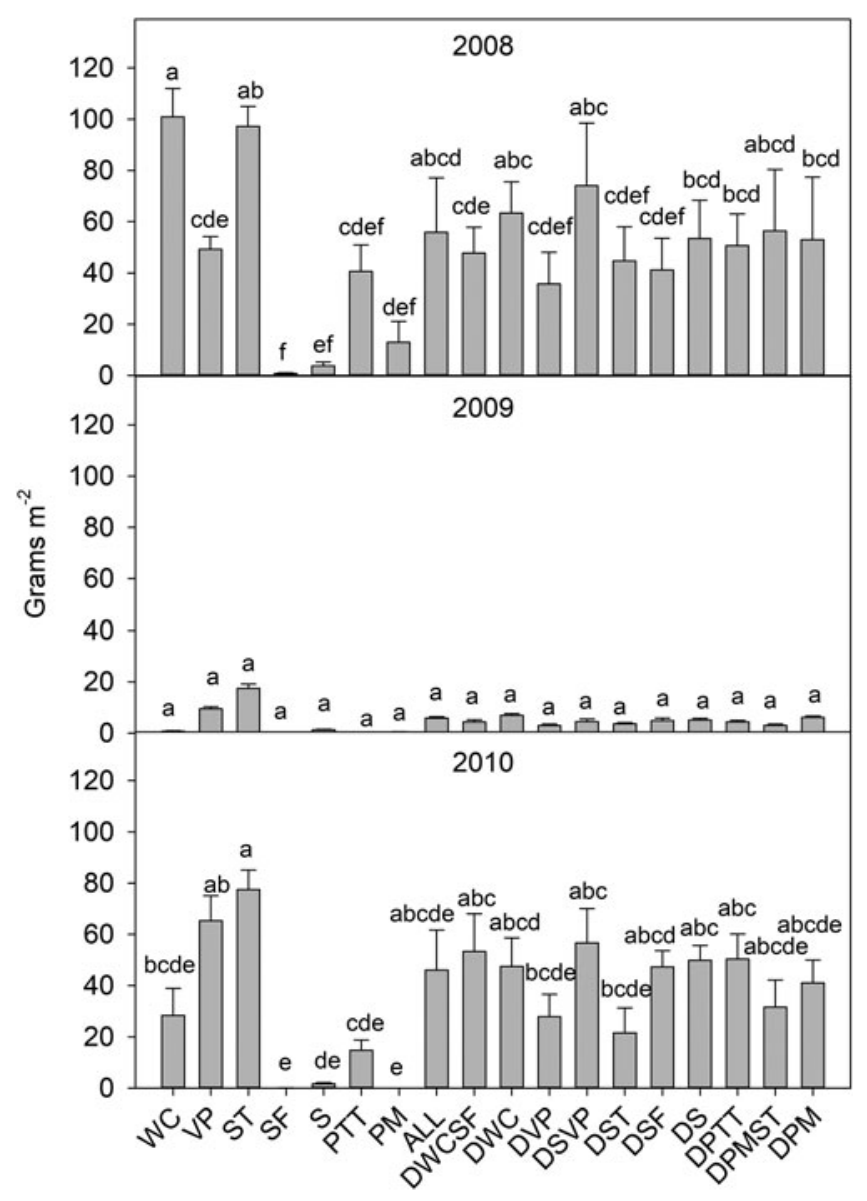

Fig. 2. Production for cover crop monocultures and mixtures recorded in 2008, 2009 and 2010. Treatments are (1) winter canola (WC); (2) vine peas (VP); (3) spring triticale (ST); (4) sunflowers (SF); (5) soybean (S); (6) purple top turnip (PTT); (7) all species (ALL); (8) ALL minus WC and SF(DWCSF); (9) ALL minus WC (DWC); (10) ALL minus VP (DVP); (11) ALL minus S and VP (DSVP); (12) ALL minus ST (DST); (13) ALL minus SF (DSF); (14) All minus S (DS); (15) ALL minus PTT (DPTT); (16) ALL minus PM and ST (DPMST); and (17) ALL minus PM (DPM).

not in 2008 or 2010 (Table 6). In 2009, $d$ was greater for the DSVP than for DSF, DS, DWC, DPM or DWCSF. The $d$ value was also greater for DVP than for DWCSF or DPM (Table 6). 
Table 4. Yields of four response crops in each year following late-seeded cover crops at research site near Mandan, ND

\begin{tabular}{lllll}
\hline Year & $\begin{array}{l}\text { Corn } \\
\mathrm{kg} \mathrm{ha}^{-1}\end{array}$ & Dry pea & Soybean & Spring wheat \\
\hline 2009 & $5896(84) \mathrm{b}^{1}$ & $1576(47) \mathrm{a}$ & $1693(49) \mathrm{b}$ & $4040(68) \mathrm{a}$ \\
\hline 2010 & $7215(101) \mathrm{a}$ & $987(24) \mathrm{b}$ & $2722(38) \mathrm{a}$ & $3195(38) \mathrm{b}$ \\
\hline 2011 & $3475(60) \mathrm{c}$ & $527(16) \mathrm{c}$ & $1371(20) \mathrm{c}$ & $793(17) \mathrm{c}$ \\
\hline
\end{tabular}

${ }^{1}$ Yields with different lower-case letter signify differences between years within response crop. Number in parenthesis indicates standard error of the yield.

Table 5. Measurements of overyielding in the cover crop mixtures

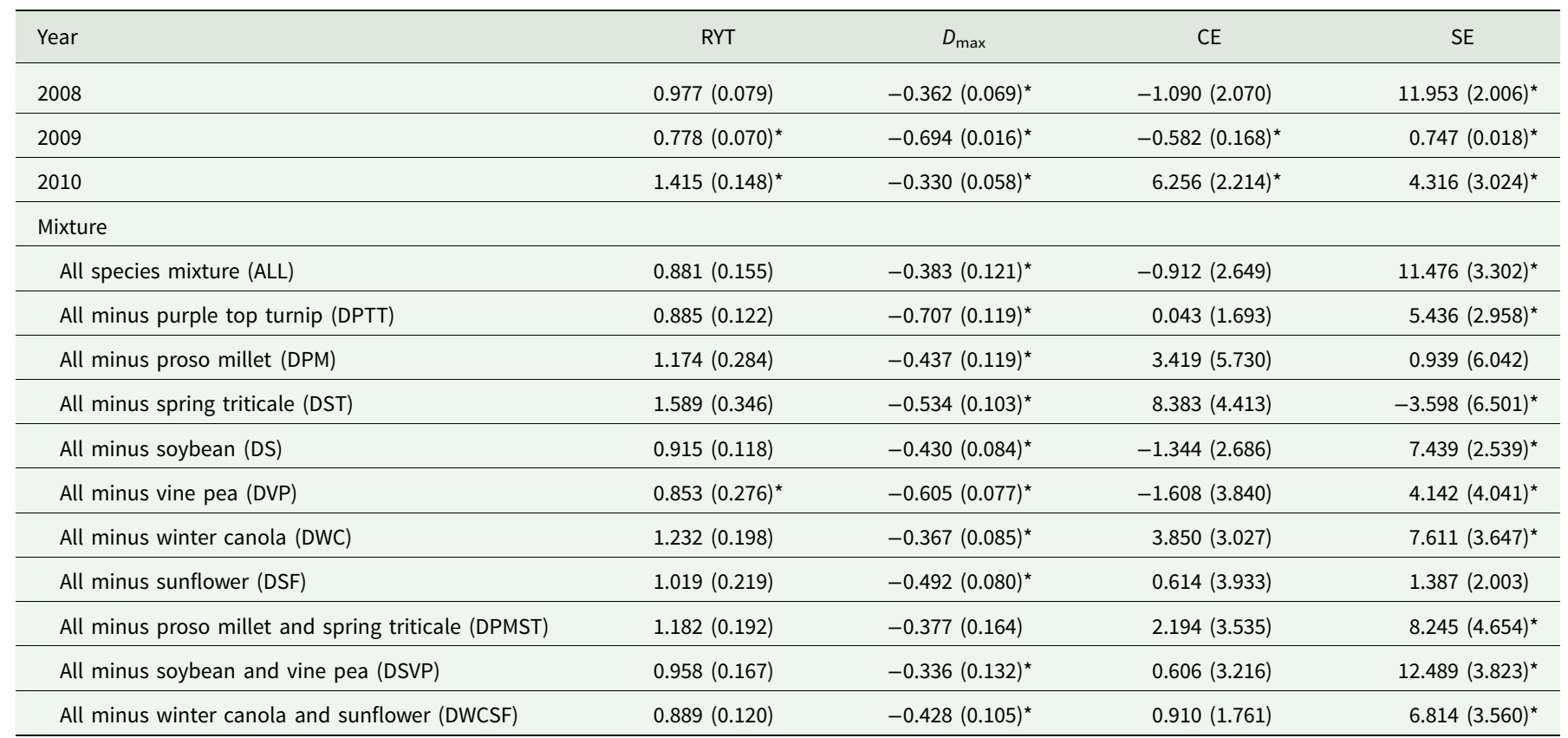

Overyielding measurements are relative yield total (RYT), transgressive overyielding ( $D_{\text {max }}$ ), complementary effects (CEs) and selection effects (SEs). Values in parenthesis indicate standard error of the mean for each value. An * following the number indicates the value is significantly different from 1 for RYT and 0 for $D_{\max }$, CE and SE.

There were year by treatment interactions for the proportion of PTT, S, ST, VP and WC in the mixtures. The proportion of PTT differed in 2008 and 2010. In 2008, there were no differences between treatments in the proportion of PTT in any treatment except for the DPTT in which PTT was not seeded. In 2010, the proportion of PTT was greater in the DPMST than in any other mixture except for DST. The DST mixture also had a greater proportion of PTT than did DWCSF, DS or DPTT (Table 6). In 2009 , the proportion of $S$ in the DPMST mixture was greater than in the DPM, DS, DSF, DSVP, DWC and ALL mixtures (Table 6).

The proportion of ST in mixtures was different in every year. The proportion of ST was greater in the DPTT, DSVP, DWC, DWCSF and ALL than in the DST or DPMST mixtures in 2008. In 2009, the proportion of ST was greater in the DSVP mixture than in any other mixture except for DVP. The DVP mixture had a greater amount of ST than did DWCSF, DSF, DPTT, DPMST or DST mixtures. ST was greater in the DWC, DS and DPM mixtures than in the DPMST or DST mixtures. In 2010, the proportion of ST in the DSVP mixture was greater than in the DST or DPMST mixtures (Table 6).

There were differences in VP between mixtures in every year, also. In 2008, VP was greater in the DPTT mixture than in the DS, DSF, DSVP, DVP or ALL mixtures. In 2009, VP made up a greater proportion of the DST mixture than any other mixture except for DPMST. The VP was also greater in the DPMST than in the DPM, DS, DSVP, DVP, DWCSF, DWC and ALL mixtures. The DPM, DWC, DSF and DWCSF treatments had a greater proportion VP than did DVP or DSVP. In 2010, VP made up less of the DVP and DSVP mixtures than the DPMST, DPTT, DST and ALL mixtures (Table 6).

The proportion of WC was different between mixtures in 2008 but not 2009 or 2010. In 2008, the proportion of WC was greater in DPMST than in DPM, DWC, DWCSF or ALL mixtures. The proportion of WC was also greater in the DS, DSF DST, DSVP and DVP than in the DWC or DWCSF mixtures (Table 6).

\section{Discussion}

Our research study evaluated the potential to seed late-season cover crops following dry peas in a northern, semi-arid climate. We hypothesized that (1) adding late-season cover crops would enhance subsequent cash crop yield and (2) cover crop mixtures would be more productive and provide greater subsequent crop yield benefits than would cover crop monocultures. Our findings did not support either hypothesis. Year, rather than cover crops, was the main driver of subsequent crop yield, and cover crop 
Table 6. Percent of each cover crop species in the species mixtures and the Berger-Parker dominance index $(d)$

\begin{tabular}{|c|c|c|c|c|c|c|c|c|}
\hline Treatment & Proso millet & Purple top turnip & Soybean & Sunflower & Spring triticale & Vine pea & Winter canola & Berger-Parker dominance index $(d)$ \\
\hline \multicolumn{9}{|l|}{2008} \\
\hline DPM & $0.0(0.0)$ & $40.0(4.5) a$ & $0.9(0.3)$ & $0.0(0.0)$ & $22.3(7.1) \mathrm{ab}$ & $23.4(5.6) a b$ & $13.4(3.4) \mathrm{bcd}$ & $0.42(0.03)$ \\
\hline DPMST & $0.0(0.0)$ & $40.0(6.7) a$ & $0.6(0.3)$ & $0.2(0.2)$ & $0.0(0.0) \mathrm{b}$ & $19.9(8.4) a b$ & $39.4(5.7) a$ & $0.49(0.03)$ \\
\hline DPTT & $0.2(0.1)$ & $0.0(0.0) \mathrm{b}$ & $1.9(0.5)$ & $0.0(0.0)$ & $36.0(7.6) a$ & $47.2(9.6) a$ & $14.8(2.3) \mathrm{bcd}$ & $0.56(0.04)$ \\
\hline DS & $0.3(0.1)$ & $34.4(5.4) a$ & $0.0(0.0)$ & $0.0(0.0)$ & $24.0(5.0) a b$ & $10.3(3.5) \mathrm{b}$ & $31.1(6.8) a b$ & $0.42(0.04)$ \\
\hline DSF & $0.2(0.1)$ & $33.4(5.2) a$ & $0.6(0.3)$ & $0.0(0.0)$ & $28.0(3.7) \mathrm{ab}$ & $14.9(4.3) \mathrm{b}$ & $22.9(5.9) \mathrm{abc}$ & $0.38(0.03)$ \\
\hline DST & $0.7(0.3)$ & $50.8(7.6) \mathrm{a}$ & $1.0(0.4)$ & $0.3(0.3)$ & $0.0(0.0) \mathrm{b}$ & $21.5(6.2) a b$ & $25.8(8.6) a b c$ & $0.55(0.05)$ \\
\hline DSVP & $0.3(0.2)$ & $32.7(5.0) a$ & $0.0(0.0)$ & $0.0(0.0)$ & $44.4(5.9) a$ & $0.0(0.0) \mathrm{b}$ & 22.6 (4.7)abc & $0.49(0.03)$ \\
\hline DVP & $0.3(0.3)$ & $42.2(14.0) a$ & $1.0(0.4)$ & $0.0(0.0)$ & $28.1(7.1) a b$ & $0.0(0.0) \mathrm{b}$ & $25.4(10.0) a b c$ & $0.56(0.09)$ \\
\hline DWC & $4.3(4.7)$ & $37.0(8.8) a$ & $0.7(0.3)$ & $0.0(0.0)$ & $40.4(7.4) a$ & $17.2(3.8) \mathrm{b}$ & $0.0(0.0) \mathrm{d}$ & $0.50(0.06)$ \\
\hline DWCSF & $0.2(0.1)$ & $36.9(9.7) \mathrm{a}$ & $1.0(0.7)$ & $0.0(0.0)$ & $41.5(8.5) a$ & $20.4(2.8) a b$ & $0.0(0.0) \mathrm{d}$ & $0.52(0.06)$ \\
\hline $\mathrm{HD}$ & $0.2(0.1)$ & $49.6(2.9) a$ & $0.6(0.2)$ & $0.0(0.0)$ & $36.6(4.3) a$ & $5.0(0.7) \mathrm{b}$ & $8.0(4.2) \mathrm{cd}$ & $0.50(0.03)$ \\
\hline \multicolumn{9}{|l|}{2009} \\
\hline DPM & $0.0(0.0)$ & $4.3(2.4)$ & $2.5(1.0) \mathrm{b}$ & $0.2(0.2)$ & $56.1(4.3) \mathrm{bc}$ & $33.9(5.4) \mathrm{cd}$ & 3. $(1.4)$ & $0.56(0.04) c$ \\
\hline DPMST & $0.0(0.0)$ & $7.4(4.4)$ & $7.0(2.8) \mathrm{a}$ & $0.0(0.0)$ & $0.0(0.0) \mathrm{d}$ & $68.2(11.0) a b$ & $17.3(9.4)$ & $0.70(0.09) a b c$ \\
\hline DPTT & $0.9(0.8)$ & $0.0(0.0)$ & $3.3(1.3) a b$ & $0.0(0.0)$ & $47.2(11.9) \mathrm{c}$ & $48.2(10.8) b c$ & $0.4(0.3)$ & $0.67(0.01) a b c$ \\
\hline DS & $0.6(0.5)$ & $2.4(1.1)$ & $0.0(0.0) \mathrm{b}$ & $0.9(0.9)$ & $58.2(7.2) b c$ & $35.0(6.3) \mathrm{cd}$ & $2.8(0.9)$ & $0.62(0.04) b c$ \\
\hline DSF & $1.7(1.5)$ & $0.5(0.3)$ & $1.7(1.7) \mathrm{b}$ & $0.0(0.0)$ & $54.4(10.2) \mathrm{c}$ & $40.0(6.7) \mathrm{bcd}$ & $1.6(1.3)$ & $0.61(0.05) \mathrm{bc}$ \\
\hline DST & $1.7(0.5)$ & $4.4(1.1)$ & $4.0(2.1) \mathrm{ab}$ & $0.0(0.0)$ & $0.0(0.0) \mathrm{d}$ & $86.1(4.0) a$ & $3.6(2.7)$ & $0.86(0.04) a b$ \\
\hline DSVP & $1.3(0.8)$ & $4.6(1.5)$ & $0.0(0.0) \mathrm{b}$ & $0.9(0.9)$ & $92.4(0.5) a$ & $0.0(0.0) \mathrm{e}$ & $0.8(0.4)$ & $0.92(<0.00) a$ \\
\hline DVP & $1.4(0.8)$ & $3.4(1.6)$ & 4.0 (1.4)ab & $1.8(1.8)$ & 88.7 (3.6)ab & $0.0(0.0) \mathrm{e}$ & $0.7(0.6)$ & $0.88(0.04) a b$ \\
\hline DWC & $2.3(1.8)$ & $1.9(1.4)$ & $0.6(0.6) \mathrm{b}$ & $0.6(0.6)$ & $58.1(4.0) \mathrm{bc}$ & $36.4(5.4) \mathrm{cd}$ & $0.2(0.2)$ & $0.60(0.05) \mathrm{bc}$ \\
\hline DWCSF & $0.1(0.1)$ & $3.2(2.1)$ & $3.4(1.3) \mathrm{ab}$ & $0.0(0.0)$ & $54.0(4.5) c$ & $39.3(5.8) \mathrm{cd}$ & $0.0(0.0)$ & $0.55(0.04) c$ \\
\hline HD & $0.4(0.3)$ & $4.4(1.4)$ & $1.0(0.6) \mathrm{b}$ & $0.0(0.0)$ & $75.0(7.1) \mathrm{abc}$ & $17.3(6.7) \mathrm{de}$ & $1.9(1.4)$ & $0.75(0.07) a b c$ \\
\hline 2010 & Proso millet & Purple top turnip & Soybean & Sunflower & Spring triticale & Vine pea & Winter canola & Berger-Parker dominance index $(d)$ \\
\hline DPM & $0.0(0.0)$ & $20.7(8.4) b c$ & $0.3(0.1)$ & $0.1(0.1)$ & $40.8(8.5) \mathrm{b}$ & $24.9(5.0) \mathrm{ab}$ & $13.3(5.5)$ & $0.48(0.03)$ \\
\hline DPMST & $0.0(0.0)$ & $54.5(7.1) a$ & $0.2(0.1)$ & $0.0(0.0)$ & $0.0(0.0) \mathrm{c}$ & $32.0(8.0) a$ & $13.3(5.9)$ & $0.54(0.06)$ \\
\hline DPTT & $0.3(0.3)$ & $0.0(0.0) \mathrm{c}$ & $0.1(0.1)$ & $0.0(0.0)$ & $64.7(6.4) \mathrm{ab}$ & $31.2(7.2) \mathrm{a}$ & $3.8(1.9)$ & $0.66(0.05)$ \\
\hline DS & $0.1(0.1)$ & $17.2(6.3) \mathrm{c}$ & $0.0(0.0)$ & $0.0(0.0)$ & $54.8(6.9) \mathrm{ab}$ & $20.2(4.4) \mathrm{ab}$ & $7.8(1.5)$ & $0.55(0.07)$ \\
\hline DSF & $0.2(0.1)$ & $19.7(6.5) b c$ & $0.1(0.1)$ & $0.0(0.0)$ & $48.0(5.0) a b$ & $22.2(5.4) a b$ & $9.8(3.5)$ & $0.51(0.06)$ \\
\hline DST & $2.5(2.1)$ & $47.4(6.5) \mathrm{ab}$ & $0.3(0.2)$ & $0.2(0.2)$ & $0.0(0.0) \mathrm{c}$ & $31.2(10.0) a$ & $18.5(7.5)$ & $0.55(0.04)$ \\
\hline DSVP & $0.1(0.9)$ & $18.6(4.2) \mathrm{c}$ & $0.0(0.0)$ & $0.0(0.0)$ & $74.0(3.0) a$ & $0.0(0.0) \mathrm{b}$ & $7.3(3.5)$ & $0.75(0.03)$ \\
\hline
\end{tabular}




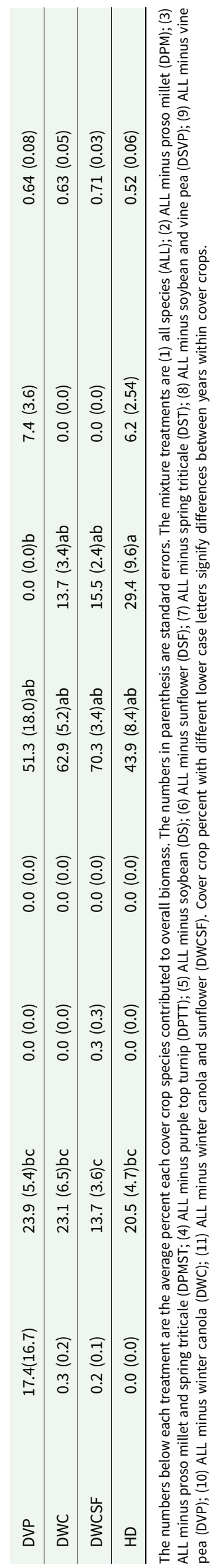

mixtures were not any more productive than monocultures and neither benefited subsequent yield. However, inclusion of lateseason cover crops did not subtract from subsequent crop yield and, depending on environmental conditions, may be a useful inclusion into crop rotations.

Surveys have suggested more producers would use cover crops if they improved crop yields (SARE and CTIC, 2015). However, the reported impact of cover crops on subsequent crop yields has been mixed with reports of cover crops either increasing, decreasing or not affecting subsequent crop yields (BlancoCanqui et al., 2015). In our study, year, rather than cover crops, drove crop yield response (Table 4). Cover crops can be problematic, in semi-arid systems, since they potentially limit soil water for the next crop (Unger and Vigil, 1998). We did not see a decrease in subsequent crop yield even though we seeded both dry pea and a cover crop in the same cropping season. Liebig et al. (2015) reported no differences in soil water content after cover crop seeding or before planting the cash crops. The cover crops were harvested in the fall and the cash crops were planted the following spring which may have allowed sufficient time for soil water recharge (Lyon et al., 2007).

The experiment was designed to evaluate the impacts of different cover crop functional groups. Understanding the impacts of different functional groups is important since functional diversity can predict multifunctionality (Blesh, 2018). Some functional groups, such as legumes can benefit subsequent crops through providing N (Sainju and Singh, 1997), although the same functional group (legumes) has been reported to reduce subsequent wheat yield when used as cover crop in place of fallow in a winter wheat-fallow system (Nielsen and Vigil, 2005). The impact of winter cover crops on subsequent corn yields depended on functional group and region (Miguez and Bollero, 2005). They found that legume cover crops had a positive impact, while grasses had a neutral and bicultures had a mixed effect on subsequent corn yields. There have also been reports that the cover crop mixture's carbon:nitrogen ratio can impact subsequent crop yields (Hunter et al., 2019). However, despite having multiple functional groups, both present and absent in different treatments, we did not see any impact on crop yield response. The impact of year indicates that environmental factors, rather than presence or absence of cover crops or cover crop functional groups, was the major driver of response crop yield.

Bi-cultures have shown increased productivity compared to monocultures (Sainju et al., 2005) at least in some years (Teasdale and Abdul-Baki, 1998), while, in Nebraska, cover crop yield tended to increase with cover crop diversity (Wortman et al., 2012a). However, in our study, at least one of the cover crop monocultures yielded more than the mixtures every year. Florence et al. (2019) suggested that mixtures did better than monocultures mainly because monoculture productivity was depressed by poorly performing species. However, predicting which monoculture would produce the most yield from year to year was challenging. For example, WC went from the highest yielding cool-season monoculture in 2008 to the lowest in 2010 (Fig. 2). Total WC production declined from $101 \mathrm{~g} \mathrm{~m}^{-2}$ in 2008 to $28 \mathrm{~g} \mathrm{~m}^{-2}$ in 2010 . However, even relatively low cover crop productivity can provide valuable forage in forage limited situations (Franzluebbers and Stuedemann, 2015). As a group, the warm-season species were particularly unproductive as late-season cover crops because of the late-seeding and slow GDD accumulation (Fig. 2). Integrating a purely cool-season cover crop mixture may increase productivity and yield stability but that combination was not included in this study. 
Although cover crop mixtures were not more productive than monocultures, it is useful to get information about how individual species performed within a mixture (Creamer et al., 1997). We utilized overyielding as a method to biological benefits to diversity. Overyielding basically measures whether individual species do better in a mixture than would be predicted by their performance in monocultures (Bonin and Tracy, 2012) and can occur in cover crop mixtures (Wortman et al., 2012b). We measured overyielding through RYT (Table 3) which is a sum of the individual relative yields of different species in a mixture (Hector, 2006). Year rather than mixture impacted overyielding as measured by RYT suggesting that environmental factors contributed more to overyielding than did species diversity. The strongest evidence of overyielding for all mixtures occurred in 2010 when RYT was significantly greater than 1 . RYT was less than 1 in 2009, which was also the year with the least cover crop yield. Transgressive overyielding, which is measured by $D_{\max }$, and indicates if mixtures yield more than the most productive monocultures (Hooper and Dukes, 2004), did not occur in our study. Overyielding in perennial species mixtures increases with time (Frankow-Lindberg et al., 2009; Bonin and Tracy, 2012) and this includes transgressive overyielding (Bonin and Tracy, 2012). The short-term nature of the annual cover crops in our study may have limited the ability of species mixtures to exhibit transgressive overyielding.

While measuring overyielding helps to compare productivity of mixtures and monocultures, it does not provide insights into mechanisms that may explain differences in productivity. The use of additional portioning equations can help to evaluate some of these differences. CEs measure ecological effects such as facilitation, complementation, niche portioning and suppression while SEs measure the impact of an individual high performing species (Bonin and Tracy, 2012). While CE and SE can be interrelated (Hooper and Dukes, 2004), the dominance of positive SE does suggest that dominant species had greater impacts on yield than did ecological effects. The SE was significantly greater than 0 in all $3 \mathrm{yr}$ and 9 of the 11 mixtures compared to only $1 \mathrm{yr}$ (2010) and none of the 11 mixtures for CE. This suggests that (1) as noted with cover crop yield, mixtures did not provide a productivity advantage over monocultures and (2) if mixtures are used, species selection is a critical component driving yield.

The CE was greatest in 2010, the wettest year of the study, while SE was greatest in 2008, the year with the greatest monoculture and mixture productivity (Fig. 2). A higher CE in wetter conditions has been reported for grasslands (Hooper and Dukes, 2004) and this study suggests that annual cover crop mixtures may follow this trend. Each year of our study was unique from a precipitation and heat accumulation perspective and our data supports Hooper and Dukes (2004) suggestion that biotic and abiotic environment, such as water availability, can impact overyielding.

Because most mixtures had a positive SE, the dominance of individual species within each mixture was assessed. Treatment differences in the Berger-Parker dominance index were only evident in 2009, which was also the year with the lowest overall productivity. This indicates greater dominance by a single species in years with low resource availability. Overall, the cool-season cover crops, regardless of functional group, made up a majority of the mixtures (Table 6).

We included warm-season cover crops as an important functional group but they did not perform well in this late-seeded study. Warm-season cover crops did not produce significant aboveground yield (Fig. 2) and with one exception made up $<5 \%$ of the species composition of the mixtures (Table 6). Warm-season cover crops received $\sim 330$ GDD in this study. More than 330 GDD were needed to either produce more than $10 \%$ of the total yield for proso millet (Maman et al., 1999) or to develop past the vegetative stage for soybean (Kandel and Akyuz, 2012) and sunflower (Sheoran et al., 1999). In contrast, cool-season GDD averaged 543 GDD, which was $65 \%$ more than the warm-season GDD. Cool-season grasses such as wheat (Triticum aestivum L.) or barley (Hordeum vulgare L.) are tillering or entering stem elongation at 540 GDD while canola and vine pea are in the late vegetative stages (Miller et al., 2018).

Late-season cover crops also need timely precipitation for establishment. The importance of timely precipitation for cover crop establishment can be seen by comparing 2008 and 2009 . Precipitation during the cover crop growing season was lowest in 2008 but cover crop production was lowest in 2009 (Fig. 2). In 2009 , the first late-season precipitation event $>1 \mathrm{~mm}$ did not occur until 17 days after seeding compared to 11 and 5 days for 2008 and 2010, respectively (Fig. 1). A lack of early precipitation in 2009 delayed emergence thereby reducing the capacity to utilize increasingly scarce GDD.

\section{Conclusions}

The use of cover crops has been increasing in dryland cropping systems. We evaluated the ability of cover crops to enhance subsequent crop yields and to evaluate the contributions of cover crop mixtures $v s$ monocultures in a semi-arid environment in the northern Great Plains. Our data did not provide evidence of cover crops enhancing subsequent crop yield or evidence that cover crop mixtures were more productive than cover crop monocultures. We did find that late-season cover crops could be produced in a semi-arid region in the northern Great Plains provided cool-season species are used and timely precipitation is received. However, yield production was generally low and erratic and costs of establishing cover crops may be high, depending on species and mixtures used.

It is important to realize that cover crops can provide benefits not directly related to yield. A previous report on the same study (Liebig et al., 2015) indicated these cover crops could help in $\mathrm{N}$ conservation. Because late-seeded cover crops have demonstrated potential for $\mathrm{N}$ conservation and limited forage production (Franzluebbers and Stuedemann, 2015), more research is needed into making them an acceptable tool for producers. Year had the greatest impact on cover crop yield in our study primarily because of the importance of timely prescription for establishment. Further research into planting times and soil moisture conditions would be valuable to producers to determine the potential for cover crop yield. Also, since cover crop benefits may accrue over years, evaluating the impact of late-seeded cover crops in a single location for multiple years may provide more insight into their potential effectiveness.

Supplementary material. The supplementary material for this article can be found at https://doi.org/10.1017/S174217052100020X.

Acknowledgements. We acknowledge the contribution of the Area IV SCDs in North Dakota for providing land to conduct research reported in this manuscript. Robert Kolberg, Delmer Schlenker, Marvin Hatzenbuhler, Nicanor Saliendra, Mary Kay Tokach, Jason Gross, Holly Johnson, Heather Matthees, Dawn Wetch, Becky Wald, Gary Brucker and numerous student biological technicians provided excellent technical support during plot establishment 
and maintenance, sample collection, sample processing and analyses and data summarization. The U.S. Department of Agriculture (USDA) prohibits discrimination in all its programs and activities on the basis of race, color, national origin, age, disability, and where applicable, sex, marital status, family status, parental status, religion, sexual orientation, genetic information, political beliefs, reprisal, or because all or part of an individual's income is derived from any public assistance program (Not all prohibited bases apply to all programs.). USDA is an equal opportunity provider and employer. Mention of commercial products and organizations in this manuscript is solely to provide specific information. It does not constitute endorsement by USDA-ARS over other products and organizations not mentioned. This research was a contribution from the Long-Term Agroecosystem Research (LTAR) network. LTAR is supported by the United States Department of Agriculture. No external funding was used in this study.

\section{References}

Aguilar J, Gramig GG, Hendrickson JR, Archer DW, Forcella F and Liebig MA (2015) Crop species diversity changes in the United States: 1978-2012. PLoS One 10, e0136580.

Anderson TW and Darling DA (1952) Asymptotic theory of certain 'goodness of fit' criteria based on stochastic processes. Annals of Mathematical Statistics 23, 193-212.

Berger WH and Parker FL (1970) Diversity of planktonic foraminifera in deep-sea sediments. Science 168, 1345-1347.

Blanco-Canqui H, Claassen MM and Presley DR (2012) Summer cover crops fix nitrogen, increase crop yield, and improve soil-crop relationships. Agronomy Journal 104, 137-147.

Blanco-Canqui H, Shaver TM, Lindquist JL, Shapiro CA, Elmore RW, Francis CA and Hergert GW (2015) Cover crops and ecosystem services: insights from studies in temperate soils. Agronomy Journal 107, 2449-2474.

Blesh J (2018) Functional traits in cover crop mixtures: biological nitrogen fixation and multifunctionality. Journal of Applied Ecology 55, 38-48.

Bonin CL and Tracy BF (2012) Diversity influences forage yield and stability in perennial prairie plant mixtures. Agriculture, Ecosystems \& Environment $162,1-7$.

Cardinale BJ, Duffy JE, Gonzalez A, Hooper DU, Perrings C, Venail P, Narwani A, MacE GM, Tilman D, Wardle DA, Kinzig AP, Daily GC, Loreau M, Grace JB, Larigauderie A, Srivastava DS and Naeem S (2012) Biodiversity loss and its impact on humanity. Nature 486, 59-67.

Creamer NG, Bennett MA and Stinner BR (1997) Evaluation of cover crop mixtures for use in vegetable production systems. HortScience 32, 866-870.

CTIC (2017) Report of the 2016-17 National Cover Crop Survey. Jt. Publ. Conserv. Technol. Inf. Center, North Cent. Reg. Sustain. Agric. Res. Educ. Program, Am. Seed Trade Assoc. West Lafayette, 1-46.

Delgado JA, Dillon MA, Sparks RT and Essah SYC (2007) A decade of advances in cover crops. Journal of Soil and Water Conservation 62, 110A-117A.

Farahani HJ, Peterson GA, Westfall DG, Sherrod LA and Ahuja LR (1998) Soil water storage in dryland cropping systems: the significance of cropping intensification. Soil Science Society of America Journal 62, 984-991.

Florence AM, Higley LG, Drijber RA, Francis CA and Lindquist JL (2019) Cover crop mixture diversity, biomass productivity, weed suppression, and stability. PLoS One 14, 1-18.

Frankow-Lindberg BE, Brophy C, Collins RP and Connolly J (2009) Biodiversity effects on yield and unsown species invasion in a temperate forage ecosystem. Annals of Botany 103, 913-921.

Franzluebbers AJ and Stuedemann JA (2015) Does grazing of cover crops impact biologically active soil carbon and nitrogen fractions under inversion or no tillage management? Journal of Soil and Water Conservation 70, 365-373.

Hansen NC, Allen BL, Baumhardt RL and Lyon DJ (2012) Research achievements and adoption of no-till, dryland cropping in the semi-arid U.S. Great Plains. Field Crops Research 132, 196-203.

Hector A (2006) Overyielding and stable species coexistence. New Phytologist $172,1-3$.

Hooper DU and Dukes JS (2004) Overyielding among plant functional groups in a long-term experiment. Ecology Letters 7, 95-105.
Hunter MC, Schipanski ME, Burgess MH, LaChance JC, Bradley BA, Barbercheck ME, Kaye JP and Mortensen DA (2019) Cover crop mixture effects on maize, soybean, and wheat yield in rotation. Agricultural \& Environmental Letters 4, 1-5.

Kandel H and Akyuz A (2012) Growing degree day model for North Dakota soybean. NDSU Crop Pest Report, North Dakota State Univ. Fargo, ND, USA.

Liebig MA, Hendrickson JR, Archer DW, Schmer MA and Nichols KA (2015) Short-term soil responses to late-seeded cover crops in a semi-arid environment. Agronomy Journal 107, 2011-2019.

Loreau M and Hector A (2001) Partitioning selection and complementarity in biodiversity experiments. Nature 412, 72-76.

Lyon DJ, Nielsen DC, Felter DG and Burgener PA (2007) Choice of summer fallow replacement crops impacts subsequent winter wheat. Agronomy Journal 99, 578.

Maman N, Mason SC, Galusha T and Clegg MD (1999) Hybrid and nitrogen influence on pearl millet production in Nebraska: yield, growth, and nitrogen uptake, and nitrogen use efficiency. Agronomy Journal 91, 737-743.

Marcillo GS and Miguez FE (2017) Corn yield response to winter cover crops: an updated meta-analysis. Journal of Soil and Water Conservation $72,226-239$.

McGuire AM, Bryant DC and Denison RF (1998) Wheat yields, nitrogen uptake, and soil moisture following winter legume cover crop vs. fallow. Agronomy Journal 90, 404-410.

Miguez FE and Bollero GA (2005) Review of corn yield response under winter cover cropping systems using meta-analytic methods. Crop Science 45, 2318-2329.

Miller P, Lanier W and Brandt S (2018) Using Growing Degree Days to Predict Plant Stages, Montana State University Extension Services, MT200103, Ag/ Extension Communications Coordinator, Communications Services, Montana State University-Bozeman. Bozeman, MT.

Murrell EG, Schipanski ME, Finney DM, Hunter MC, Burgess MH, Lachance JC, Baraibar B, White CM, Mortensen DA and Kaye JP (2017) Achieving diverse cover crop mixtures: effects of planting date and seeding rate. Agronomy Journal 109, 259-271.

Mutch DR and Martin TE (1998) Cover crops. Michigan F. Crop Ecol. Manag. Biol. Process. Product. Environ. Qual, 44-53.

NASS (2020) Quick Stats [WWW Document]. Quick Stats, USDA, Natl. Agric. Stat. Serv. Available at https://quickstats.nass.usda.gov/ (accessed 12.2.20).

Nielsen DC and Vigil MF (2005) Legume green fallow effect on soil water content at wheat planting and wheat yield. Agronomy Journal 97, 684-689.

Nielsen DC, Lyon DJ, Hergert GW, Higgins RK, Calderón FJ and Vigil M (2015) Cover crop mixtures do not use water differently than single-species plantings. Agronomy Journal 107, 1025-1038.

North Dakota Agricultural Weather Network [WWW Document] (2016) NDAWN, North Dakota State Univ. Available at https://ndawn.ndsu. nodak.edu/ (accessed 8.30.16).

Roth RT, Ruffatti MD, O'Rourke PD and Armstrong SD (2018) A cost analysis approach to valuing cover crop environmental and nitrogen cycling benefits: a central Illinois on farm case study. Agricultural Systems 159, 69-77.

Sainju UM and Singh B (1997) Winter cover crops for sustainable agricultural systems: influence on soil properties, water quality, and crop yields. HortScience 32, 21-28.

Sainju UM, Whitehead WF and Singh BP (2005) Biculture legume-cereal cover crops for enhanced biomass yield and carbon and nitrogen. Agronomy Journal 97, 1403-1412.

SARE and CTIC (2015) 2014-2015 Cover Crop Survey 45 pages.

Sheoran RK, Yadava TP, Niwas RAM, Chandra N and Kumar L (1999) Phenological development in relation to thermal units in sunflower. Cereal Research Communications 27, 427-432.

Smith RG, Gross KL and Robertson GP (2008) Effects of crop diversity on agroecosystem function: crop yield response. Ecosystems 11, 355-366.

Smith RG, Atwood LW and Warren ND (2014) Increased productivity of a cover crop mixture is not associated with enhanced agroecosystem services. PLoS One 9, e97351. https://doi.org/10.1371/journal.pone.0097351

Snapp SS, Swinton SM, Labarta R, Mutch D, Black JR, Leep R and Nyiraneza J (2005) Evaluating cover crops for benefits, costs 
and performance within cropping system niches. Agronomy Journal 97, 322-332.

Teasdale JR and Abdul-Baki AA (1998) Comparison of mixtures vs. Monocultures of cover crops for fresh-market tomato production with and without herbicide. HortScience 33, 1163-1166.

Tilman D, Reich PB, Knops J, Wedin D, Mielke T and Lehman C (2001) Diversity and productivity in a longterm grassland experiment. Science 294(5543), 843-845.
Unger PW and Vigil MF (1998) Cover crop effects on soil water relationships. Journal of Soil and Water Conservation 53, 200-207.

Wortman SE, Francis CA, Bernards ML, Drijber RA and Lindquist JL (2012a) Optimizing cover crop benefits with diverse mixtures and an alternative termination method. Agronomy Journal 104, 1425-1435. Wortman SE, Francis CA and Lindquist JL (2012b) Cover crop mixtures for the western corn belt: opportunities for increased productivity and stability. Agronomy Journal 104, 699-705. 